\title{
The challenge of managing the commercial harvesting of the sea urchin Paracentrotus lividus: advanced approaches are required
}

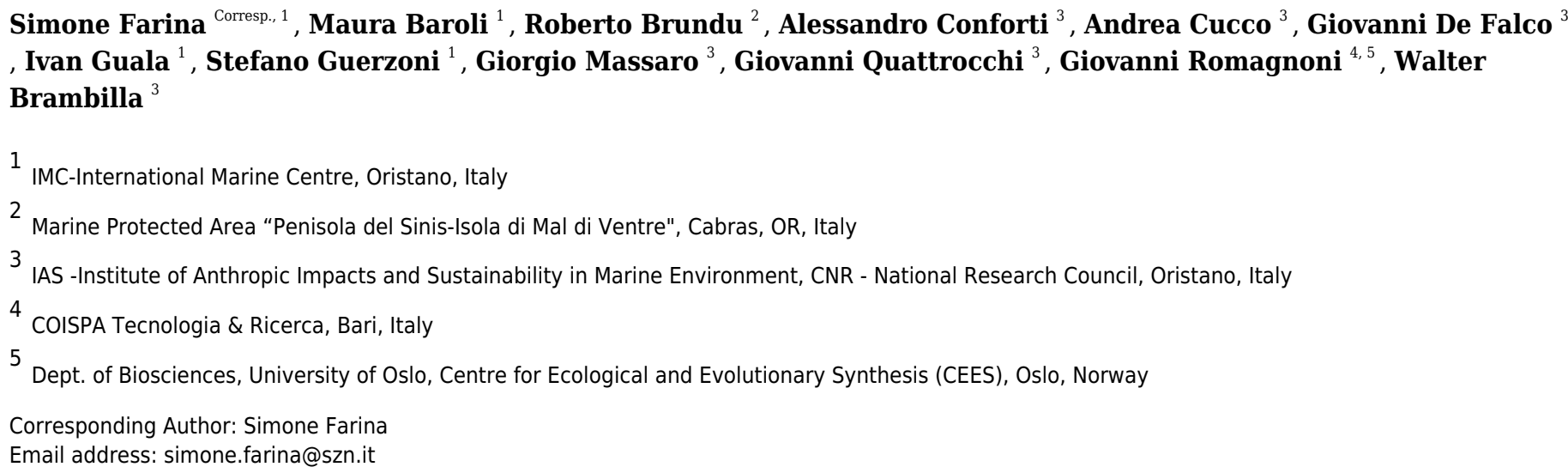

Sea urchins act as a keystone herbivore in marine coastal ecosystems, regulating macrophyte density, which offers refuge for multiple species. In the Mediterranean Sea, both the sea urchin Paracentrotus lividus and fish preying on it are highly valuable target species for artisanal fisheries. As a consequence of the interactions between fish, sea urchins and macrophyte, fishing leads to trophic disorders with detrimental consequences for biodiversity and fisheries. In Sardinia (Western Mediterranean Sea), regulations for sea urchin harvesting have been in place since the mid 90s. However, given the important ecological role of $P$. lividus, the single-species fishery management may fail to take into account important ecosystem interactions. Hence, a deeper understanding of population dynamics, their dependence on environmental constraints and multispecies interactions may help achieve long-term sustainable use of this resource. This work aims to highlight how sea urchin population structure varies spatially in relation to local environmental constraints and species interactions, with implications for their management. The study area (Sinis Peninsula, West Sardinia, Italy) that includes a Marine Reserve was divided into five sectors. These display combinations of the environmental constraints influencing sea urchin population dynamics, namely type of habitat (calcareous rock, granite, basalt, patchy and continuous meadows of Posidonia oceanica), average bottom current speed and predatory fish abundance. Size-frequency distribution of sea urchins under commercial size ( $<5 \mathrm{~cm}$ diameter size) assessed during the period from 2004 to 2007, before the population collapse in 2010, were compared for sectors and types of habitat. Specific correlations between recruits (0-1 cm diameter size) and bottom current speeds 
and between middle-sized sea urchins ( $2-5 \mathrm{~cm}$ diameter size) and predatory fish abundance were assessed. Parameters representing habitat spatial configuration (patch density, perimeter-to-area ratio, mean patch size, largest patch index, interspersion/juxtaposition index) were calculated and their influence on sea urchin density assessed. The density of sea urchins under commercial size was significantly higher in calcareous rock and was positively and significantly influenced by the density and average size of the rocky habitat patches. Recruits were significantly abundant in rocky habitats, while they were almost absent in Posidonia meadows. The density of middle-sized sea urchins was more abundant in calcareous rock than in basalt, granite or Posidonia. High densities of recruits resulted significantly correlated to low values of average bottom current speed, while a negative trend between the abundance of middle-sized sea urchins and predatory fish was found. Our results point out the need to account for the environmental constraints influencing local sea urchin density in fisheries management. 
1 The challenge of managing the commercial harvesting

2 of the sea urchin Paracentrotus lividus: advanced

\section{approaches are required}

${ }^{1}$ IMC- International Marine Centre, Loc. Sa Mardini, Torre Grande, 09170 Oristano, Italy

${ }^{2}$ CNR - National Research Council, IAS -Institute of Anthropic Impacts and Sustainability in

Marine Environment, Loc. Sa Mardini, Torre Grande, 09170 Oristano, Italy.

${ }^{4}$ COISPA Tecnologia \& Ricerca, Via dei Trulli 18/20, Bari, Italy

${ }^{5}$ Centre for Ecological and Evolutionary Synthesis (CEES), Dept. of Biosciences, University of Oslo, Norway

*corresponding author e-mail: simone.farina@snz.it; present address: IMC - Ischia Marine Centre, Stazione Zoologica Anton Dohrn, Punta San Pietro, 80077, Ischia, Naples, Italy 


\section{Abstract}

Sea urchins act as a keystone herbivore in marine coastal ecosystems, regulating macrophyte density, which offers refuge for multiple species. In the Mediterranean Sea, both the sea urchin Paracentrotus lividus and fish preying on it are highly valuable target species for artisanal fisheries. As a consequence of the interactions between fish, sea urchins and macrophyte, fishing leads to trophic disorders with detrimental consequences for biodiversity and fisheries. In since the mid 90s. However, given the important ecological role of $P$. lividus, the single-species fishery management may fail to take into account important ecosystem interactions. Hence, a deeper understanding of population dynamics, their dependence on environmental constraints and multispecies interactions may help achieve long-term sustainable use of this resource. This work aims to highlight how sea urchin population structure varies spatially in relation to local environmental constraints and species interactions, with implications for their management. The study area (Sinis Peninsula, West Sardinia, Italy) that includes a Marine Reserve was divided into five sectors. These display combinations of the environmental constraints influencing sea urchin population dynamics, namely type of habitat (calcareous rock, granite, basalt, patchy and continuous meadows of Posidonia oceanica), average bottom current speed and predatory fish abundance. Size-frequency distribution of sea urchins under commercial size $(<5 \mathrm{~cm}$ diameter size) assessed during the period from 2004 to 2007, before the population collapse in 2010, were compared for sectors and types of habitat. Specific correlations between recruits $(0-1 \mathrm{~cm}$ diameter size) and bottom current speeds and between middle-sized sea urchins $(2-5 \mathrm{~cm}$ diameter size) and predatory fish abundance were assessed. Parameters representing habitat spatial configuration (patch density, perimeter-to-area ratio, mean patch size, largest patch index, interspersion/juxtaposition index) were calculated and their influence on sea urchin density assessed. The density of sea urchins under commercial size was significantly higher in calcareous rock and was positively and significantly influenced by the density and average size of the rocky habitat patches. Recruits were significantly abundant in rocky habitats, while they were almost absent in Posidonia meadows. The density of middle-sized sea urchins was more abundant in calcareous rock than in basalt, granite or Posidonia. High densities of recruits resulted significantly correlated to low values of average bottom current speed, while a negative trend between the abundance of middle-sized sea urchins and predatory fish was found. Our results point out the need to account for the environmental constraints influencing local sea urchin density in fisheries management. 
48

49

50

51

52

53

54

\section{Introduction}

The continuous decline of fishery catches during the last decades has pushed many fishermen to switch to new species at lower trophic levels (Anderson et al., 2011). One of the clearest examples from coastal ecosystems is the overexploitation of species involved in the typical tri-trophic interaction "fish-sea urchins-macroalgae" (Jackson et al., 2001). In the Mediterranean Sea, the interaction between the sea breams Diplodus spp. and Spaurus aurata, the sea urchin Paracentrotus lividus and coastal macroalgal forests follows this paradigm.

Paracentrotus lividus is one of the most important herbivores of Mediterranean benthic ecosystems (e.g. Hereu et al., 2005; Prado et al., 2012). The impact of overfishing through the impairment of predatory control on $P$. lividus determines a significant loss of macroalgal communities and biodiversity (Micheli et al., 2005; Giakoumi et al., 2012; Sala et al., 2012; Wallner-Hahn et al., 2015). For this reason, in the Mediterranean Sea it is widely accepted that $P$. lividus harvesting may be a potentially effective method for mitigating overgrazing in areas of severe overfishing (e.g. Piazzi \& Ceccherelli, 2019).

Concurrently, targeted harvesting of sea urchin is progressively increasing worldwide (Andrew et al., 2002; James et al., 2016). Direct extraction is resulting in the collapse of local populations (Tegner \& Dayton, 1977; Pennington, 1985; Levitan, Sewell \& Fu-Shiang Chia, 1992; Levitan \& Sewell, 1998) and in community-level effects, with rapid development of large, brown algae and changes in the composition of fish and benthic communities (e.g. Steneck et al., 2002). Sea urchin fisheries generally follow the short-term "boom-and-bust" pattern of many invertebrate fisheries. They start as a small-scale activity that undergoes a phase of rapid expansion followed by a phase of full exploitation that lead to the exhaustion of the resource (Andrew et al., 2002). 
72

communities needs to be considered in the development of sustainable urchin fisheries (Tegner $\&$ Dayton, 2000; Norderhaug et al., 2020).

In light of these considerations, an integrated management strategy for social and ecological systems has been developed in many regions where this situation has occurred (e.g. Moreno et al., 2006; Perry, Zhang \& Harbo, 2002). There are a number of well-managed and sustainable sea urchin fisheries around the world that tend to rely on a good general knowledge of the biology of the urchin species present in the area as well as a sound understanding of the dynamics of sea urchin populations (James et al., 2016).

In New Zealand, for example, between 2002 and 2003, the sea urchin species Evechinus chloroticus was introduced into the quota management system of fishing, thanks to the support of the detailed biological information (Miller \& Abraham, 2011). The quota management system is used to set the total allowed catch in twelve different fishing sectors according to the assessment of a set of biological criteria (Miller \& Abraham, 2011). Fishing areas are classified in relation to growth conditions of the gonads, spawning rate, larval diffusion and the connectivity of local populations (Kritzer \& Sale, 2004; James, Heath \& Unwin, 2007; James \& Heath, 2008; James et al., 2009; Wing, 2009).

In Mediterranean Sea, P. lividus is locally harvested in few regions by recreational and artisanal fisheries. In Sardinia (Italy, Western Mediterranean Sea) for example, where sea urchin populations have suffered unsustainable pressure since the early 2000s (Guidetti, Terlizzi \& Boero, 2004; Pais et al., 2007, 2012; Ceccherelli et al., 2011), sea urchin harvesting is managed by a regional decree (Department of Environmental Protection Decree No. 276 of March 3, 1994 and subsequent amendments). This introduced a combination of measures including licences, quotas, 
94 fishing techniques allowed, minimum size and seasonal closures. Regulation changed substantially

95 after 2009: before 2009, professional fishermen (115 to 161 licences) were authorized to collect

96 up to 3000 sea urchins per day by scuba diving along the entire coast of the Island (between

97 November and April), with more restrictive regulations inside marine protected areas. After 2009,

98 the number of regional licences increased to 189 , but stricter regulations have been introduced for

99 the harvesting, transportation, storage and processing of the sea urchins (RAS, Autonomous

100 Region of Sardinia, decree no. 2524/DecA/102 of October 7, 2009). Daily catches per fisherman

101 were reduced to 2000, while the minimum catch size remained unchanged over the years $(>5 \mathrm{~cm}$

102 diameter size).

The Peninsula of Sinis, in the central western coast of Sardinia, including the local Marine

104 Protected Area "Penisola del Sinis, Isola di Mal di Ventre" (Marine Reserve from now on), is one

105 of the main harvesting hotspots. Inside the Marine Reserve, some harvesting restrictions are

106 applied: only resident professional fishermen are allowed to harvest sea urchins, for a maximum

107 catch quota of 500 sea urchins per day per fisherman. The number of licenced fishermen varied

108 from 125 in 2001 up to over 270 between 2004 and 2007 (including non-specialised artisanal

109 fishers with special permission to harvest also sea urchins in this area). Nowadays, licences issued

110 decreased progressively down to 54 and recreational fishing has been banned (before 2009 it was

111 allowed for residents only, with max 50 urchins per day)

112 Despite the tighter regulations in place since 2009, individuals larger than $5 \mathrm{~cm}$ diameter

113 (minimum commercial size) are still infrequent both inside and outside the Marine Reserve. In

114 fact, scientific monitoring in the Marine Reserve has shown a dramatic depletion both in

115 commercial sizes ( $>5 \mathrm{~cm}$ diameter size) and in the whole population: sea urchin $>5 \mathrm{~cm}$ firstly

116 declined between 2004 and 2005, while the whole population dramatically declined since 2010 
117 (Pieraccini, Coppa \& De Lucia, 2016) with 65\% and 75\% reductions, respectively (Coppa et al.,

118 2018). The year 2010 can be thus considered the onset of the crisis of P. lividus in the area. Monitoring of sea urchin population structure (defined hereafter as abundance and age/size

120 structure in the population) is performed on an ad-hoc basis in Sardinia in order to provide a 121 scientific ground for stock assessment (Cau et al 2007). The first regional surveys of sea urchins 122 in Sardinia were carried out in 2001, 2003 and again in 2007. As one of the main harvesting 123 hotspots, the Peninsula of Sinis has been closely monitored since 2004. and 2007 (before the population collapse) to provide relevant information on population structure 126 (under the commercial size of $5 \mathrm{~cm}$ diameter) when the impact of harvesting was still limited to

127

128

129

130

132

133

134

135

136

137

138 the commercial class (Pieraccini, Coppa \& De Lucia, 2016). These pre-collapse data represent a precious reference for understanding natural relationships between local population dynamics and the environmental constraints in the study area.

In general, recruitment and predation are considered the main ecological processes driving P. lividus population dynamics and shaping population structure locally (Fig.1; Sala \& Zabala, 1996; Goñi et al., 2000). Larval supply is strongly influenced by coastal hydrodynamics (Fenaux, Cellario \& Rassoulzadegan, 1988; Harmelin-Vivien et al., 2000; Prado et al., 2012; Farina et al., 2018), while the nature of the substrate, the type of habitat and the abundance of predatory fish strongly influence settlement success and post-settlement survival (Boudouresque \& Verlaque, 2001; Tomas, Turon \& Romero, 2004; Hereu et al., 2005; Oliva et al., 2016). Settlement on rocky habitats is generally higher than in seagrass Posidonia oceanica, where the abundance of cryptic predators determines a high mortality rate (Tomas, Turon \& Romero, 2004). 
Once in the benthos, predation becomes the most important ecological driver of sea urchin 140 distribution (Hereu et al., 2005; Tomas, Romero \& Turon, 2005). The labrid Coris julis and the commercial sea breams Diplodus spp. and Sparus aurata represent the main predators of recruits and middle-sized sea urchins respectively (Sala, 1997; Guidetti, Boero \& Bussotti, 2005). The predation risk of sea urchins strongly depends on the availability of shelters provided by the structure of the habitats and their spatial configuration (Farina et al., 2009, 2017; Pagès et al., 2012) until the urchins reach the safety size of $\sim 5 \mathrm{~cm}$ (Guidetti et al., 2004).

We divided the study area into five fishing sectors with varying levels of environmental constraints influencing P. lividus recruitment and predation. Specifically, we focused on types of habitat (i.e. Calcareous rock substrate, Granite substrate, Basalt substrate, patchy and continuous meadows of Posidonia oceanica), and on a pool of variables describing habitat spatial configuration (patch density, perimeter-to-area ratio, mean patch size, largest patch index and the interspersion/juxtaposition index) which strongly influence shelter and food availability for sea urchins (e.g. Hereu et al., 2005; Farina et al., 2017). A circulation model of bottom current speed was used to approximate coastal hydrodynamics that strongly influence larval diffusion and sea urchin settlement (Farina et al., 2018). Finally, predatory fish abundance provides approximative information about potential predation activity along the fishing sectors (Guidetti, 2007).

recruit density (0-1 cm diameter size) and middle-sized sea urchin density (2-5 $\mathrm{cm}$ diameter size) are estimated for each fishing sector and type of habitat. Density of commercial size class $(>5 \mathrm{~cm}$ diameter test) was also reported but not considered in the analysis because already compromised by harvesting in the study period (Pieraccini, Coppa \& De Lucia, 2016). 
162 the importance of local hydrodynamics on population recovery and of predator activity on

163 population structure are evaluated as a relationship a) of the average bottom current speed to the

164 density of recruits, and b) between the densities of predatory fish and middle-sized sea urchins, as

165 the size-class range potentially vulnerable to fish predators. Finally, the influence of spatial

166 configurations of rocky habitats on the total density of sea urchins under commercial size $(<5 \mathrm{~cm}$

167 diameter size) is estimated.

168 Taking advantage of the valuable dataset before the collapse of 2010, we attempt to capture

169 the natural relationships between local population dynamics and the environmental constrains in

170 the study area, providing a precious reference point to understand the mechanisms driving

171 population structure before its collapse. This is a key step toward an improved comprehension of

172 local population dynamics and a prerequisite for basing fishing quota allocation

173 In order to avoid a collapse of sea urchin populations in this area, and to achieve long term

174 sustainability of the fishery, a major change in the management strategy is necessary (e.g. Ouréns,

175 Naya \& Freire, 2015). The aim of this study is therefore to provide evidence on the importance of

176 embedding spatial and temporal environmental processes in the assessment of the stock

177 sustainability towards a scientifically sound, ecosystem-based fisheries management that allows

178 an integrated management of sea urchins and their predators in the Peninsula of Sinis.

Study Area 

of Oristano and Su Pallosu Bay (Peninsula of Sinis) (Fig.2). This area includes the local Marine Protected Area of "Penisola del Sinis, Isola di Mal di Ventre", which was established in 1997 and

187

188

190

covers a surface of $250 \mathrm{Km}^{2}$ (Fig. 2). The full protection area is $5 \mathrm{Km}^{2}$ (Guala et al., 2008), while the remaining zones are intensively frequented by fishermen (Pieraccini, Coppa \& De Lucia, 2016). The study area is limited to the bathymetry of $5 \pm 1 \mathrm{~m}$ (mean depth at which the harvesters usually work) and it is subdivided into five fishing sectors (Table 1). Study sector 1 is identified in the portion of coast located outside the Marine Reserve from Su Pallosu Bay to the northern boundary of the Marine Reserve, including Cape Mannu (Fig.2). Sectors 2 and 3 encompass the stretch of coast inside the Marine Reserve that is exposed to the open sea, while sector 4 represents the Marine Reserve islands of Mal di Ventre and Catalano. Finally, sector 5, at the southern border of the Marine Reserve, includes part of the Gulf of Oristano.

The seabed of the study area is composed of bedrock of different natures: Palaeozoic granite basement, cropping out around Mal di Ventre Island; Pliocene basalt rock in the Cape San Marco area and surrounding Catalano Island (Fais, Klingele \& Lecca, 1996; De Falco et al., 2003; Duncan et al., 2011; Conforti et al., 2016); and the Miocene and Quaternary Calcareous rocks located all along the study area coastline (Lecca \& Carboni, 2007). These different types of substrate morphology influence the distribution of Posidonia oceanica; the meadow shows a patchy pattern where the matte is on the bedrock and a continuous pattern where the matte lies on the unconsolidated sediments (Fig.2). The meadow is continuous on the eastern side of Mal di Ventre Island and inside the Gulf of Oristano, while $P$. oceanica shows a patchy meadow pattern in the rest of the study area (De Falco et al., 2008).

Peer) reviewing PDF | (2020:03:47281:2:0:NEW 3 Sep 2020) 
Along the coastal area, the average bottom current speed (Fig.3) strongly influences the

207

208

209

210

211

212

213

214

215

216

217

218

219

220

221

222

223

224

225

226

227

228

abundance of sea urchin recruits (Farina et al., 2018). The water circulation in this area is mainly

promoted by the action of the winds which are predominantly from the North-West, the Mistral

wind, and from the South-West, the Libeccio wind, with average speeds of $7 \mathrm{~m} / \mathrm{s}$ and with peaks

around $20 \mathrm{~m} / \mathrm{s}$ (Zecchetto et al., 2016). Such two prevalent wind regimes may generate intense

flows towards the south, in the case of Mistral events, and weaker northward flows, in the case of

Libeccio events. In both cases, within the Gulf of Oristano, recirculation cells develop in

correspondence to the leeway side of the main two Gulf capes. We refer to Cucco et al. (2006,

2012) for a detailed description of sea current circulation in the study area.

\section{Environmental constraints}

Within the sectors, on the basis of the occurrence of different rocky substrates and Posidonia oceanica meadows, the environmental areas inhabited by sea urchins are defined as types of habitat (Abercrombie, Hickman \& Johnson, 1966): Calcareous rock (CR), Granite (GR), Basalt (BA), Posidonia oceanica patchy meadow (PM) and Posidonia oceanica continuous meadow (CM).

The geomorphology was described through habitat mapping (Fig. 2). Available data consisted of morpho-bathymetric data, aerial images and several geo-datasets. To ease processing and data sharing among researchers, all available data were integrated and organized in a geodatabase implemented through a GIS and the software suite Geoinformation Enabling Toolkit StarterKit ${ }^{\circledR}$ (GET-IT), (Fugazza, Oggioni \& Carrara; Pavesi et al., 2016; Lanucara et al., 2017; Brambilla et al., 2019) that was developed by researchers from the Italian National Research Council within the framework of the RITMARE research project. 

coverage of the seabed (MESH, 2008). Seafloor mapping has been made by imposing clear

231

232

233

234

235

236

237

238

239

240

241

242

243

244

245

246

247

248

249

250

251 boundaries between different morphotypes (Fig. 2) to provide representations of how are they structured. Habitats alternate heterogeneously along the coast. A pool of variables describing the basic characteristic of their spatial configuration was estimated in each sector with the free software Fragstats 4.1 (McGarial \& Marks, 1995). The estimated variables are Patch Density of types of habitat on the total landscape area $\left(\mathrm{PD}\right.$, patch/ $\left.\mathrm{Km}^{2}\right)$, Perimeter-to-area ratio $(\mathrm{P} / \mathrm{A}$ ratio, 1/m), Mean Patch Size of types of habitat (MPS, $\mathrm{Km}^{2}$ ), the Largest Patch Index (LPI, \%) as the percentage of landscape area occupied by the largest patch of a type of habitat and Interspersion/Juxtaposition Index (IJI, \%) which measures the degree of aggregation or "clumpiness" of a map based on adjacency of patches of the same type of habitat (O'Neill et al., 1988) (Table 2).

The average bottom current speed in the investigated area was obtained by means of a numerical modelling previously applicated in Farina et al., (2018). A three-dimensional hydrodynamic and wind wave model, SHYFEM-WWM (Umgiesser et al., 2004), previously used to reproduce the wind-wave and the 3D water circulation in the Western Sardinian Sea (Cucco et al., 2006, 2016; De Falco et al., 2008), was adopted.

In Farina et al., (2018), the authors reported the model solution for the biennium 2009 and 2010 since it is highly representative of the climate in the Sinis Peninsula (see Appendix 1 in there). The same solutions were used here to describe the water circulation in the first 10 meters of water depth. Hourly data of the sea water speed at the bottom were averaged between January and June, corresponding to the period of active local recruitment (Table 1; Fig.3) (Prado et al., 2012; Farina et al., 2018).

Peer) reviewing PDF | (2020:03:47281:2:0:NEW 3 Sep 2020) 
252 Finally, from a multi-year series of fish biomass data recollection, we extrapolated the abundance

253 of sea urchin predatory fish for each sector from 2004 to 2007 with the exception of sector 5 (Marra

254 et al., 2016). Data represent the abundance of the commercial sea breams Diplodus spp., Sparus

255 aurata in the shallow water over the rocky bottoms (5 metres in depth) collected using Underwater

256 Visual Census (Table 1) (Marra et al., 2016). In these years, the reserve effect on fish biomass was

257 not evident and no significant differences were detected between inside and outside the Marine

258 Reserve with the exception of the sea bream that were more abundant inside (Marra et al., 2016; 259 Table.1).

\section{Sea urchin population structure}

Sea urchin population structure was estimated for each type of habitat in the study sectors from a multi-year series of data from 2004 to 2007 (before the population collapsed). During this period, 79 samplings were carried out following a standard protocol at depths between 2 and $10 \mathrm{~m}$

265 (Guala et al., 2008). Data were collected as previously described in Farina et al. (2018). Specifically, for each site and type of habitat, sea urchin density was estimated as the number of individuals per square meter $\left(\mathrm{ind} / \mathrm{m}^{2}\right)$ and the sizes of the individuals (without spines) were measured with callipers to the closest $\mathrm{mm}$. survived until approximately one year after their settlement (Ouréns et al., 2013) and middle-sized sea urchins as individuals of size class range $2-5 \mathrm{~cm}$ (diameter size), vulnerable to predatory fish.

272 Recruits and middle-sized sea urchins together constitute the under commercial size. Sea urchins

273 larger than $5 \mathrm{~cm}$ diameter represent the commercial stock and are also estimated but this size-class 
274 is not considered in the analysis carried out in relation with the environmental factors since its

275 density was already reduced to low values by human activity before 2007 (Pieraccini, Coppa \&

276 De Lucia, 2016).

277 Sea urchin population density and structure are estimated for each type of habitat and

278 sector for before their collapse (Table 3, Fig.4). We carried out an analysis of variance of the sea

279 urchin density for the under-commercial-sized $(<5 \mathrm{~cm}$ diameter test), recruit-sized $(0-1 \mathrm{~cm}$

280 diameter size) and middle-sized sea urchins $(2-5 \mathrm{~cm}$ diameter test) function of "sector" and

281 "habitat" as fixed factors. Assumptions of normal distribution and homogeneity of response

282 variables were tested using D'Agostino-Pearson and Cochran's tests. The densities of sea urchins

283 under commercial size and those of the middle-size followed a normal distribution with

284 unbalanced replicates and were analysed with General Linear Model with Gaussian family

285 distribution (Zuur et al., 2009). Whereas, given the non-normal distribution and the high amount

286 of zeros in recruit density, the analysis of variance of recruits was performed with General Linear

287 Model with Negative Binomial Distribution and certain zero Inflation in order to avoid biased

288 parameter estimates and standard errors (Zuur et al., 2009). All the model validations are provided

289 graphically (see Supplementary material).

290

\section{Relationship between population structure and environmental conditions}

Spearman's rank correlation coefficient as a non-parametric measure of rank

correlation was carried out between non-normal distribution values of recruit density and the

test, was used to estimate the statistical relationship between normally distributed values of density for middle-sized sea urchins and the density of predatory fish. 
297 The Generalized Linear Model (GLM) with Poisson family distribution was performed in order to

298 assess the influences of a pool of variables representing the basic configuration of the rocky

299 habitats on total sea urchin density for those under the commercial size. Patch Density, Perimeter-

300 to-area ratio, Mean Patch Size, Largest Patch Index and Interspersion/Juxtaposition Index (IJI, \%)

301 are previously estimated (see above) and used as predictors for sea urchins density (commercial

302 stock excluded). The stepwise forward regression technique was used to select the more 303 conservative model (Whittingham et al., 2006).

304 Given the lack of data on fish visual census in Posidonia oceanica and since recruits are 305 considerably underestimated inside meadows (Oliva et al., 2016), the patchy meadow and 306 continuous meadow types of habitats were excluded a priori from all these analyses. Analyses 307 were performed using R Studio (R Core Team, 2014).

\section{Results}

310

\section{Environmental constraints}

Sector 1 is the largest sector with an area of $12.7 \mathrm{Km}^{2}$ (Fig.2). The average current speed was $0.05 \pm 0.003 \mathrm{~m} / \mathrm{s}$ (Fig.3) which was the slowest current measured in the recruitment period (from January to June; see Table 1). Conversely, sector 4 is the smallest sector with a total area of $3.8 \mathrm{Km}^{2}$ (Fig.2) and the highest predatory fish abundance of $84.6 \pm 12.6 \mathrm{ind} / 125 \mathrm{~m}^{2}$ (Table 1). Sectors 2 and 3 extend $5.1 \mathrm{Km}^{2}$ and $4.4 \mathrm{Km}^{2}$ respectively (Fig.2) with intermediate values for both

317 bottom current speed average and predatory fish abundance (see Table 1 and Fig.3). Finally, sector

3185 covers a total area of $11.9 \mathrm{Km}^{2}$ with a similar bottom current speed average for sector 3 , while data on predatory fish abundance were not available (Table 1). 

per $\mathrm{Km}^{2}$ In sector 2, Calcareous rock (CR-2) presents the most extensive surface of the habitats in

323 the sector with the highest patch aggregation (98.9\% of IJI) of all the habitats in the study area (see 324 Table 2). a surface of 2 and $1 \mathrm{Km}^{2}$ respectively and both habitats present a Patch Density of 0.32 per $\mathrm{Km}^{2}$

327 (Table 2). Basalt (BA-3) is distributed over $0.1 \mathrm{~km}^{2}$ in both sectors 3 and 4. In Sector 4, Granite (GR-4) covers $1.8 \mathrm{Km}^{2}$ (Table 2). Finally, in sector 5 Posidonia oceanica continuous meadow (CM-5) represents $11.1 \mathrm{Km}^{2}$ of the surface in the sector with the largest patch covering $42.6 \%$ of the total area (Table 2). Continuous meadow is also present in sector 4 but sea urchins have never been sampled there. A variable proportion of sandy bottom is present in all the sectors with the exception of sector 4 .

\section{Sea urchin population structure}

Sector 1, located outside the Marine Reserve, presented the highest sea urchin density of $9.9 \pm 1.1$ ind $/ \mathrm{m}^{2}$, but the lowest proportion of commercial stock (15.1\%; Table 1). Inside the Marine Reserve, sea urchin density ranged from the low density of sector 5 of $2.5 \pm 0.2 \mathrm{ind} / \mathrm{m}^{2}$, with a proportion of $20 \%$ commercial stock, to the high density of $9.8 \pm 1.2 \mathrm{ind} / \mathrm{m}^{2}$ in sector 4 and with a proportion of commercial stock of $28.7 \%$ (Table 1 ).

The density of specimens under commercial size differ significantly between habitats ( $p$-value $<$ 341 $0.001)$ and between sectors $(p$-value $=0.02$; Table $4 a)$. Among the types of habitat, the highest sea 
342 urchin density for specimens under commercial size was found in CR-1: $16.3 \pm 1.4 \mathrm{ind} / \mathrm{m}^{2}$ (Figure

343 4, Table 3). High values were also found in CR-2, CR-3 (10.6 \pm 1.3 and $10.1 \pm 0.8 \mathrm{ind} / \mathrm{m}^{2}$

344 respectively) and in GR-4 $\left(11 \pm 1.1 \mathrm{ind} / \mathrm{m}^{2}\right)$. Otherwise, the lowest sea urchin density was estimated

345 in correspondence to CM-5 (Table 3).

346 Densities for both recruits and middle-sized sea urchins were significantly different among habitats

347 and sectors (p-values $<0.001$; Fig. 4 and Table $4 \mathrm{~b}$ and 4c). Recruits were significantly more

348 abundant in sector 1 and sector 4 where they were $3.6 \pm 0.6 \mathrm{ind} / \mathrm{m}^{2}$ in CR-1, $1.9 \pm 0.6 \mathrm{ind} / \mathrm{m}^{2}$ in

349 GR-4 and $1.5 \pm 1.1 \mathrm{ind} / \mathrm{m}^{2}$ in BA-4 (Table 3 and $4 \mathrm{~b}$ ). Meanwhile, no recruits were found in PM-1,

350 PM-2, BA-3 and CM-5 (Fig.4, Table 3). The highest average value of density for middle-sized sea

351 urchins was found in CR-1 at $(7.2 \pm 0.8 \mathrm{ind} / \mathrm{m})$. Average density values for CR-2 and CR-3 (6.3

$352 \pm 0.9 \mathrm{ind} / \mathrm{m}^{2}$ and $5.4 \pm 0.7 \mathrm{ind} / \mathrm{m}^{2}$ respectively) were higher than for BA-3, BA-4 and GR-4 (3.1

$353 \pm 1.1,0.5 \pm 0.2 \mathrm{ind} / \mathrm{m}^{2}$ and $3.3 \pm 0.8 \mathrm{ind} / \mathrm{m}^{2}$ respectively) (Table 3 ). In $\mathrm{CM}-5$, the density of middle-

354 sized sea urchins was $1.9 \pm 0.5 \mathrm{ind} / \mathrm{m}^{2}$ (Fig.4, Table 3).

355

356

Relationship between population structure and environmental conditions

357

Values of recruit density in rocky habitats (Calcareous rocky, Basalt and Granite) follow

a non-normal distribution due to the high number of sampled zeros. Accordingly, Speraman's non-

parametrical rank correlation test was performed between recruit density and average bottom

current speed and a negative significant relationship was found (Spearman's rank correlation p-

value $=0.002932 ;$ rho $=-0.3972998 ;$ Fig.5a). The density of middle-sized sea urchins following

normal distribution was correlated to the predatory fish density using Peason's correlation test and 
363 the variables resulted in a significant negative correlation (Pearson's correlation p-value =

3640.04268 , correlation coefficient $=-0.5118654$; Fig. 5b).

365

366

367

368

369

370

371

372

373

374

375

376

The General Linear Model highlights high significant influences of Patch Density (PD; pvalue $<0.001)$ and significant influence of the Mean Patch Size (MPS; p-value $<0.001$ ) on sea urchin density for specimens under commercial size. The proportion of the variance explained by the Minimal Adequate Model is roughly 50\% (see Table 5 and Fig. S5).

\section{Discussion}

The surveys carried out between 2004 and 2007 revealed conspicuous differences in sea urchin density across fishing sectors and types of habitat. In general, rocky habitats of Calcareous rock, Basalt and Granite supported larger sea urchin populations than the habitats characterized by Posidonia oceanica.

Excluding the commercial component of the stock whose density was distorted by intensive fishing, the sea urchin density for specimens under commercial size in rocky habitats was significantly higher in Calcareous rock. Moreover, considering results obtained from the analysis on the spatial configuration, larger and more dense patches seems to further enhance sea urchin density in Calcareous rock.

In fact sector 1 was outside the Marine Reserve and had the lowest proportion of commercial stock, Calcareous rock in this sector presented a large surface $\left(4.5 \mathrm{Km}^{2}\right)$ with high Patch Density (one patch per $\mathrm{Km}^{2}$ ) which supported a density of sea urchin under commercial size approximately twice that of calcareous rock in sectors 2 and 3. Specifically, recruit density in 
386 Calcareous rock of sector 1 was 6 and 4 times higher than in the Calcareous rock of sectors 2 and

3873 respectively, and 2 and 2.5 times higher than in the Granite and Basalt of sector 4 respectively.

388 The density of middle-sized sea urchins resulted more than 2 times higher in Calcareous rock in

389 general (sectors 1, 2, 3) than in the Granite and Basalt (sector 4). Finally, in the Posidonia oceanica

390 patchy meadows, recruit density was negligible everywhere, and similarly for the middle -sized

391 sea urchins in the continuous meadow of sector 5.

Population structures analysed responded to the high variability of the environmental constraints observed along this stretch of coast. From January to June, when spawning occurs (Loi et al., 2017) and settlement is supposed to be over (estimating 20-30 days for the planktonic phase once the eggs are fertilized, Lozano et al., 1995), the average bottom current speed was slowest in sector 1. It was almost half the speed of sectors 2 and 4 and a third less than in sectors 3 and 5 . The weak, negative correlation between recruits and bottom current speed is a distant approximation of the real influence of hydrodinamics on population recruitment. This correlation was performed due to the lack of data on larvae and settlers during these years. In general, the influence of current on recruitment can serve as an indicator of effective connectivity between areas (Romagnoni et al., 2020). However, sea urchin density during the post-settlement phase 402 experiences important decreases due to predators (Hereu, Zabala \& Sala, 2008) and, as consequence, bottom current speed should be more closely correlated to larvae and settlers than to 404 recruits. The low values of the average bottom current speed $(<0.1 \mathrm{~m} / \mathrm{s})$ correspond to recruit 405 densities above $3.5 \mathrm{ind} / \mathrm{m}^{2}$. It is noteworthy that the average bottom current speed on the Calcareous rock of sector 1 is always below this critical threshold. Accordingly, this condition 407 seems to support the existence of local standing circulation structures that determine a higher regime of natural recruitment (Farina et al., 2018). 
After recruitment, predation is the second main process regulating sea urchin population 410 structure on a local scale (Guidetti, 2004; Hereu, Zabala \& Sala, 2008; Boada et al., 2015). Adult

411 sea urchins are preyed on by few fish species, especially the sea breams which are targeted by 412 artisanal fisheries (Guidetti, 2006). During 2004-2007, there was a negative correlation between 413 the abundances of the sea breams and middle-sized sea urchins. Low abundances of predatory fish 414 were found outside the Marine Reserve in sector 1, most likely due to the strong pressure exerted 415 by recreational spearfishing (Marra et al., 2016). Conversely, in sector 4- the Islands inside the 416 Marine Reserve- the density of sea breams was higher than in the other sectors (Marra et al. 2016). The reduced accessibility of the islands compared to the other coastal sectors could have offered seabreams protection from recreational spear fishermen, allowing higher abundance in this sector. Consistently with this theory, the lowest density of middle-sized sea urchins was found in sector 4, supporting the possibility of a higher level of predation in this area due to higher density of predatory fish. Contreras \& Fahrig, 1998; Kondoh, 2003; Prado et al., 2008; Farina et al., 2017). This is typically caused by fragmentation processes, which generally result in increasing habitat complexity as patch perimeter- to- area ratios increase (Ranney, Bruner \& Levenson, 1981). The opposite condition is designed by the calcareous rock in sector 1 . High-density patches with large surfaces dampen visual predation of fish providing efficient shelters to middle-sized sea urchins and recruits 428 as well (Hereu et al., 2005). 
431 seem along this stretch of coast. Such heterogeneity might indicate that the sea urchin population

432 in this region could be composed of multiple, smaller populations with their own dynamics,

433 potentially connected via larval dispersion. In fact, the long planktonic early life-stage (between

434 20-30 days according to Lozano et al., 1995) could theoretically make sea urchin populations well

435 connected (López et al., 1998; Morgan et al., 2000; Prado et al., 2012; Treml et al., 2012).

436 However, in this area larval dispersion could be strongly dependent on the bottom current speed

437 (Farina et al 2018). The presence of "source- sink" dynamics via larval dispersal mediated by

438 bottom current speed could affect conservation and management strategies for sustainable fisheries

439 (Romagnoni et al., 2020; Kritzer and Sale 2004; Kerr et al., 2016). This is especially important for

440 conservation requirements in a Marine Reserve (Paterno et al., 2017) and it is an aspect of concern

441 for future research in this area.

The strength of connectivity depends strongly on the abundance of reproducers. Since commercial harvesting depletes the main reproducers (i.e. size class $>5 \mathrm{~cm}$ ), middle-sized sea urchins play an important role in the population's recovery (Loi et al., 2017). However, this size class is highly vulnerable to predators. For this reason, harvesting of this size class should be limited in conditions of high predation mortality. This could be the case of the Islands of sector 4 , where the sea urchin population seemed to suffer a higher predation pressure than in the other sectors.

Farina et al. $(2009,2014)$ found high proportions of middle-sized sea urchins in patchy meadows in accordance with the efficient shelter that Posidonia oceanica leaves provide from the visual mechanism of predatory fish. However, the three-dimensional structure of large seagrass

452 meadows can become a 'death trap' in the presence of high densities of bottom predators (Farina 
454 characterized by a large, continuous meadow of Posidonia oceanica (De Falco et al., 2008). Here,

455 the low density of $P$. lividus could be related to the abundance of whelks (e.g. Hexalplex trunculus,

456 authors pers. obs.), which is known as effective predators of sea urchins (e.g. Farina et al., 2016)

457 and whose proliferation is probably favoured by the bio-deposits that accumulate beneath the

458 nearby mussel farms (Inglis \& Gust, 2003).

In order to achieve long-term sustainable exploitation of marine resources, fisheries

management should account for the key processes regulating population dynamics on a relevant spatial and temporal scale (Hilborn \& Walters, 1992). Despite the approximations and data limitations, our analysis identified spatial heterogeneity in sea urchin stock abundance related to local conditions as well as emergent natural relationships between sea urchin population dynamics, help in advancing management in the area. has been proposed to provide a scientific basis for management in Sardinia based on ad-hoc data and on regular scientific monitoring of sea urchin density (Addis et al., 2009). However, given the key role played by $P$. lividus in coastal ecosystems, advanced approaches could be required to 471 provide long-term sustainable exploitation that considers the importance of environmental constraints in influencing local sea urchin population structure through the ecological drivers of

473 recruitment and predation (Miller \& Abraham, 2011). For example, fisheries models with explicit 474 inclusion of spatial dynamics (Kritzer and Sale 2004; Kerr et al., 2016) or multispecies dynamics 475 allow for the testing of alternative management strategies (Christensen \& Walters, 2004; Fulton et 476 al., 2004; Spedicato et al., 2010). 

measures for regulating the fishing effort on specific components of the populations (for example, reducing harvesting of key size classes) or areas (e.g. areas with high predation mortality, or in key "source" areas).

The Peninsula of Sinis offers a unique case study, where ecological and economic knowledge is building up, and the involved stakeholders, including small-scale fisheries

organizations, Marine Reserve and local administration are demanding a science-based management system. There is currently momentum toward the implementation of a long-term vision which entails a data collection procedure aiming to provide management strategies for the sustainable management of sea urchin fisheries. These would combine the objectives of conservation of ecological features and of traditional and socio-economics values. Moreover, achieving sustainable fishing of both resources -sea urchins and sea breams- should enhance, as a cascade effect, the conservation prospective for macrophyte communities, which are pivotal for 491 ensuring a high environmental quality and support nursery of other benthic species.

\section{Acknowledgements}

The authors want to thank all researchers and students who contributed to creating a historical dataset on sea urchin density in this area through their work. This work was supported financially by the Interreg V A Italy France Maritime 2014-2020 Cooperation Program, project "Gestione 


\section{References}

502 Abercrombie M, Hickman CJ, Johnson M. 1966. Dictionary of Biology. London: Penguin 503 Reference Books.

504

505

506

507

508

509

510

511

512

513

514

515

516

517

518

519

520

521

Addis P, Secci M, Manunza A, Corrias S, Niffoi A, Cau A. 2009. A geostatistical approach for the stock assessment of the edible sea urchin, Paracentrotus lividus, in four coastal zones of Southern and West Sardinia (SW Italy, Mediterranean Sea). Fisheries Research 100: 215221. DOI: 10.1016/j.fishres.2009.07.008.

Anderson SC, Mills Flemming J, Watson R, Lotze HK. 2011. Rapid Global Expansion of Invertebrate Fisheries: Trends, Drivers, and Ecosystem Effects. PLoS ONE 6:e14735. DOI: 10.1371/journal.pone.0014735.

Andrew NL, Agatsuma Y, Ballesteros E, Bazhin AG, Creaser EP, Barnes DKA, Botsford LW, Bradbury A, Campbell A, Dixon JD, Einarsson S, Gerring PK, Hebert K, Hunter M, Hur SB, Johnson CR, Juinio-Menez MA, Kalvass P, Miller RJ, Moreno CA, Palleiro JS, Rivas D, Robinson SML, Schroeter SC, Steneck RS, Vadas RL, Woodby DA, Xiaoqi Z. 2002. Status and management of world sea urchin fisheries. In: Oceanography and Marine Biology an annual review. 11 New Fetter Lane, London ec4p 4ee, England: Taylor \& Francis LTD, 343425.

Bender D, Contreras T, Fahrig L. 1998. Habitat loss and population decline: a meta-analysis of the patch size effect. Ecology 79:517-533.

Boada J, Arthur R, Farina S, Santana Y, Mascaró O, Romero J, Alcoverro T. 2015. Hotspots of predation persist outside marine reserves in the historically fished Mediterranean Sea. 
523 Boudouresque CF, Verlaque M. 2001. Ecology of Paracentrotus lividus. In: Miller J ed. Edible 524 Sea Urchins: Biology and Ecology. Elsevier Science, 177-216.

525 Brambilla W, Conforti A, Simeone S, Carrara P, Lanucara S, De Falco G. 2019. Data set of 526 submerged sand deposits organised in an interoperable spatial data infrastructure (Western 527 Sardinia, Mediterranean Sea). Earth System Science Data 11:515-527. DOI: 10.5194/essd528

Cau A, Addis P, Corrias S, Corpino G, Manunza A, Secci M, Niffoi A, Atzori F, Corrias F, Lai L. 2007. Valutazione degli stocks del riccio di mare (Paracentrotus lividus): dinamica di

Ceccherelli G, Pais A, Pinna S, Sechi N, Chessa LA. 2011. Human impact on Paracentrotus lividus: the result of harvest restrictions and accessibility of locations. Marine Biology

Christensen V, Walters CJ. 2004. Ecopath with Ecosim: Methods, capabilities and limitations. Ecological Modelling 172:109-139. DOI: 10.1016/j.ecolmodel.2003.09.003.

Conforti A, Budillon F, Tonielli R, De Falco G. 2016. A newly discovered Pliocene volcanic field on the western Sardinia continental margin (western Mediterranean). Geo-Marine Letters 36:1-14. DOI: doi.org/10.1007/s00367-015-0428-0. popolazione di riccio di mare Paracentrotus lividus. Cabras (Oristano).

542 Cucco A, Perilli A, De Falco G, Ghezzo M, Umgiesser G. 2006. Water circulation and transport 
543 timescales in the Gulf of Oristano. Chemistry and Ecology 22:307-331. DOI:

$544 \quad$ http://doi.org/10.1080/02757540600670364.

545 Cucco A, Quattrocchi G, Olita A, Fazioli L, Ribotti A, Sinerchia M, Tedesco C, Sorgente R. 2016.

546 Hydrodynamic modeling of coastal seas: the role of tidal dynamics in the Messina Strait,

547 Western Mediterranean Sea. Natural Hazards and Earth System Sciences Discussions:1-36.

548 Cucco A, Sinerchia M, Ribotti A, Olita A, Fazioli L, Perilli A, Sorgente B, Borghini M, Schroeder

549 K, Sorgente R. 2012. A high-resolution real-time forecasting system for predicting the fate of

550 oil spills in the Strait of Bonifacio (western Mediterranean Sea). Marine Pollution Bulletin

551 64:1186-1200. DOI: https://doi.org/10.1016/j.marpolbul.2012.03.019.

552 Duncan R, Ginesu S, Secchi F, Sias S. 2011. The recent evolution of the Sinis region (western 553 coast of Sardinia, Italy) on the basis of new radiometric data of Pliocenic volcanism.

554 Geografia Fisica e Dinamica Quaternaria 34:175-181. DOI:

555 doi:10.4461/GFDQ.2011.34.16.

556 Fais S, Klingele EE, Lecca L. 1996. Oligo-Miocene half graben structure in western Sardinian

557 Shelf (western Mediterranean): reflection seismic and aeromagnetic data comparison,.

558 Marine Geology 133:203-222. DOI: doi.org/10.1016/0025-3227(96)00030-8.

559 De Falco G, Baroli M, Cucco A, Simeone S. 2008. Intrabasinal conditions promoting the 560 development of a biogenic carbonate sedimentary facies associated with the seagrass $561 \quad$ Posidonia oceanica. Continental Shelf Research 28:797-812.

562 De Falco G, Molinaroli E, Baroli M, Bellacicco S. 2003. Grain size and compositional trends of 563 sediments from Posidonia oceanica meadows to beach shore, Sardinia, Western 
565 Farina S, Arthur R, Pagès JF, Prado P, Romero J, Vergés A, Hyndes G, Heck KL, Glenos S, 566 Alcoverro T. 2014. Differences in predator composition alter the direction of structure567 mediated predation risk in macrophyte communities. Oikos 123:1311-1322. DOI: 568

Farina S, Guala I, Oliva S, Piazzi L, Pires da Silva R, Ceccherelli G. 2016. The Seagrass Effect 10.1111/oik.01382.

Farina S, Oltra A, Boada J, Bartumeus F, Romero J, Alcoverro T. 2017. Generation and Turned Upside Down Changes the Prospective of Sea Urchin Survival and Landscape maintenance of predation hotspots of a functionally important herbivore in a patchy habitat mosaic. Functional Ecology:0-3. DOI: 0000-0003-0169-8044.

Farina S, Quattrocchi G, Guala I, Cucco A. 2018. Hydrodynamic patterns favouring sea urchin recruitment in coastal areas: A Mediterranean study case. Marine Environmental Research.

Farina S, Tomas F, Prado P, Romero J, Alcoverro T. 2009. Seagrass meadow structure alters interactions between the sea urchin Paracentrotus lividus and its predators. Marine Ecology Progress Series 377:131-137. DOI: 10.3354/meps07692. the larva of Paracentrotus lividus (Lamarck) to quantity and quality of food. In: Burke RD, Mladenov PV, Lambert P, Parsley RL eds. Echinoderm biology. Rotterdam: AA Balkema, $259-266$. 
585 Fugazza C, Oggioni A, Carrara P. RITMARE: Linked Open Data for Italian Marine Research. 586 ERCIMNews 96:17-1. DOI: ://ercim-news.ercim.eu/en96/special/ritmare-linked-open-data587 for-italian-.

588 Fulton EA, Parslow JS, Smith ADM, Johnson CR. 2004. Biogeochemical marine ecosystem 589 models II : the effect of physiological detail on model performance. 173:371-406. DOI: $590 \quad$ 10.1016/j.ecolmodel.2003.09.024.

591 Giakoumi S, Cebrian E, Kokkoris GD, Ballesteros E, Sala E. 2012. Relationships between fish, 592 sea urchins and macroalgae: The structure of shallow rocky sublittoral communities in the 593 Cyclades, Eastern Mediterranean. Estuarine Coastal and Shelf Science 109:1-10. DOI: 594 https://doi.org/10.1016/j.ecss.2011.06.004.

595 596

597

598

601

602

603

604

605

Goñi R, Harmelin-Vivien M, Badalamenti F, Le Diréach L, Bernard G. 2000. Introductory guide to methods for selected ecological studies in marine reserves.

Guala I, Massaro G, de Lucia GA, De Falco G, Domenici P. 2008. Sinis-Mal di Ventre. In: Planes S, Garcia-Charton J, Marcos C, Perez-Ruzafa A eds. EMPAFISH Project, Booklet. 158.

Guidetti P. 2004. Consumers of sea urchins, Paracentrotus lividus and Arbacia lixula, in shallow Mediterranean rocky reefs. Helgoland Marine Research 58:110-116. DOI: 10.1007/s10152004-0176-4.

Guidetti P. 2006. Potential of marine reserves to cause community-wide changes beyond their boundaries. Conservation Biology 21:540-545. DOI: 10.1111/j.1523-1739.2007.00657.x.

Guidetti P. 2007. Predator diversity and density affect levels of predation upon strongly interactive species in temperate rocky reefs. Oecologia 154:513-520. DOI: 10.1007/s00442-007-0845- 
607 Guidetti P, Bianchi CN, Chiantore M, Schiaparelli S, Morri C, Cattaneo-Vietti R. 2004. Living on 608 the rocks: Substrate mineralogy and the structure of subtidal rocky substrate communities in 609 the Mediterranean Sea. Marine Ecology Progress Series 274:57-68. DOI: $610 \quad 10.3354 / \operatorname{meps} 274057$.

611 Guidetti P, Boero F, Bussotti S. 2005. Evaluating the effects of protection on fish predators and 612 sea urchins in shallow artificial rocky habitats: a case study in the northern Adriatic Sea. $613 \quad$ Marine Environmental Research 59:333-348.

614 Guidetti P, Terlizzi A, Boero F. 2004. Effects of the edible sea urchin, Paracentrotus lividus, 615 fishery along the Apulian rocky coast (SE Italy, Mediterranean Sea). Fisheries Research 616 66:287-297. DOI: 10.1016/S0165-7836(03)00206-6.

617 Harmelin-Vivien R, Badalamenti F, Le Diréach L, G. B. 2000. Introductory guide to methods for 618 selected ecological studies in marine reserves. Fr: GIS Posidonie.

619 Hereu B, Zabala M, Linares C, Sala E. 2005. The effects of predator abundance and habitat 620 structural complexity on survival of juvenile sea urchins. Marine Biology 146:293-299. DOI: 10.1007/s00227-004-1439-y.

Hereu B, Zabala M, Sala E. 2008. Multiple controls of community structure and dynamics in a sublittoral marine environment. Ecology 89:3423-3435.

Hilborn R, Walters CJ. 1992. Quantitative fisheries stock assessment, choice, dynamics and uncertainty. London: Chapman and Hall. DOI: 10.1007/978-1-4615-3598-0. 
627 of benthic predators. Journal of Applied Ecology 40:1077-1089. DOI: 10.1111/j.1365$628 \quad 2664.2003 .00860 . x$.

629 Jackson JBC, Kirby MX, Berger WH, Bjorndal KA, Botsford LW, Bourque BJ, Bradbury RH, 630 Cooke R, Erlandson J, Estes JA, Hughes TP, Kidwell S, Lange CB, Lenihan HS, Pandolfi 631 JM, Peterson CH, Steneck RS, Tegner MJ, Warner RR. 2001. Historical Overfishing and the 632 Recent Collapse of Coastal Ecosystems. Science 293:629-637. DOI: $633 \quad 10.1126 /$ science. 1059199.

634 635

James P. 2006. A comparison of roe enhancement of the sea urchin Evechinus chloroticus in seabased and land-based cages. Aquaculture 253:290-300.

James P, Heath P. 2008. The effects of season, temperature and photoperiod on the gonad development of Evechinus chloroticus. Aquaculture 285:67-77.

James P, Heath P, Green K, Wright J. 2009. The effect of elevated temperature on roe enhancement of Evechinus chloroticus collected from two latitudes. Aquaculture 288:273-279.

James P, Heath P, Unwin M. 2007. The effects of season, temperature and initial gonad condition on roe enhancement of the sea urchin Evechinus chloroticus. Aquaculture 270:115-131.

James P, Noble C, Hannon C, Stefánsson G, Pórarinsdóttir G, Ziemer N, Lochead J. 2016. Sea urchin fisheries, management and policy review. :1-19. DOI: 10.13140/RG.2.2.29800.88326.

Kondoh M. 2003. Habitat fragmentation resulting in overgrazing by herbivores . journal of Theoretical biology 225:453-460.

Kritzer JP, Sale PF. 2004. Metapopulation ecology in the sea:from Levins' model to marine ecology and fisheries science. Fish and Fisheries 5:131-140. DOI: Doi 10.1111/J.1467- 
649 Lanucara S, Oggioni A, Modica G, Carrara P. 2017. Interoperable Sharing and Visualization of 650 Geological Data and Instruments: A Proof of Concept. In: Computational Science and Its 651 Applications - ICCSA 2017, Lecture Notes in Computer Science. DOI: doi.org/10.1007/978652 3-319-62401-3_42, 2017.

653 Lecca L, Carboni S. 2007. The Tyrrhenian section of San Giovanni Di Sinis (Sardinia): 654 Stratigraphic record of an irregular single high stand. Rivista Italiana di Paleontologia e $655 \quad$ Stratigrafia 113:509-523.

656 Levitan D, Sewell M. 1998. Fertilization success in free-spawning marine invertebrates: review of 657 the evidence and fisheries implications. Canadian Special Publication of Fisheries and 658 Aquatic Sciences:159-164.

659 Levitan DR, Sewell MA, Fu-Shiang Chia. 1992. How distribution and abundance influence 660 fertilization success in the sea urchin Strongylocentrotus franciscanus. Ecology 73:248-254.

661 Loi B, Guala I, Pires R, Brundu G, Baroli M, Farina S. 2017. Hard time to be parents ? Sea urchin 662 fishery shifts potential reproductive contribution of population onto the shoulders of the 663 young adults. :1-22. DOI: 10.7717/peerj.3067.

664

665

666

667

668

López S, Turon X, Montero E, Palacín C, Duarte CM, Tarjuelo I. 1998. Larval abundance, recruitment and early mortality in Paracentrotus lividus (Echinoidea). Interannual variability and plankton-benthos coupling. Marine Ecology Progress Series 172:239-251. DOI: $10.3354 /$ meps 172239 .

Lozano J, Galera J, Lopez S, Turon X, Palacin C, Morera G. 1995. Biological cycles and 
669

670

671

672

673

674

675

676

677

678

679

680

681

682

683

684

685

686

687

688

689

recruitment of Paracentrotus lividus (Echinodermata: Echinoidea) in two contrasting habitats. Marine Ecology Progress Series 122:179-192.

Marra S, Coppa S, Camedda A, Mazzoldi C, Wrachien F, Massaro G, De Lucia GA. 2016. Recovery trends of commercial fish: The case of an underperforming mediterranean marine protected area. PLOS ONE 11:1-22. DOI: 10.1371/journal.pone.0146391.

McGarial K, Marks BJ. 1995. FRAGSTAT: Spatial pattern analysis program for quantifying landscape structure. United States Department of Agriculture, Pacific Northwest Research Station:120 pages.

Micheli F, Benedetti-Cecchi L, Gambaccini S, Bertocci I, Borsini C, Osio GC, Romano F. 2005. Cascading human impacts, marine protected areas; and the structure of Mediterranrean reef assemblages. Ecological Monographs 75:81-102. DOI: 10.1890/03-4058.

Miller S, Abraham E. 2011. Characterisation of New Zealand kina fisheries. In: New Zealand Fisheries Assessment Report.

Moreno CA, Barahona N, Molinet C, Orensanz L, Parma AM, Zuleta A. 2006. From Crisis to Institutional Sustainability in the Chilean Sea Urchin Fishery. In: Fisheries Management: Progress Towards Sustainability 43-67. DOI: 10.1002/9780470996072.ch3.

Morgan LE, Wing SR, Botsford LW, Lundquist CJ, Diehl JM. 2000. Spatial variability in red sea urchin (Strongylocentrotus franciscanus) recruitment in northern California. Fisheries Oceanography 9:83-98. DOI: 10.1046/j.1365-2419.2000.00124.x.

Norderhaug KM, Nedreaas K, Huserbråten M, Moland E. 2020. Depletion of coastal predatory fish sub-stocks coincided with the largest sea urchin grazing event observed in the NE 
Atlantic. Ambio https://doi.org/10.1007/s13280-020-01362-4.

691 O’Neill R V., Krummel JR, Gardner RH, Sugihara G, Jackson B, DeAngelis DL, Milne BT, Turner 692 MG, Zygmunt B, Christensen SW, Dale VH, Graham RL. 1988. Indices of landscape pattern. 693 Landscape Ecology 1:153-162. DOI: 10.1007/BF00162741.

694 Oliva S, Farina S, Pinna S, Guala I, Agnetta D, Ariotti P, Mura F, Checcherelli G. 2016. 695 Determinants of Paracentrotus lividus sea urchin recruitment under oligotrophic conditions: 696 implications for conservation management. Marine Environmentalfile://D:/bibliografia.Data/bibliografia pdfloliva et al. 2016.pdf Research

Ouréns R, Fernández L, Fernández-Boán M, Naya I, Freire J. 2013. Reproductive dynamics of the sea urchin Paracentrotus lividus on the Galicia coast (NW Spain): Effects of habitat and

Ouréns R, Naya I, Freire J. 2015. Mismatch between biological, exploitation, and governance scales and ineffective management of sea urchin (Paracentrotus lividus) fisheries in Galicia.

Pagès JF, Farina S, Gera A, Arthur R, Romero J, Alcoverro T. 2012. Indirect interactions in 706 seagrasses: fish herbivores increase predation risk to sea urchins by modifying plant traits.

Pais A, Chessa L a., Serra S, Ruiu A, Meloni G, Donno Y. 2007. The impact of commercial and 709 recreational harvesting for Paracentrotus lividus on shallow rocky reef sea urchin Functional Ecology 26:1015-1023. DOI: 10.1111/j.1365-2435.2012.02038.x. 
597. DOI: 10.1016/j.ecss.2007.02.011.

712 Pais A, Serra S, Meloni G, Saba S, Ceccherelli G. 2012. Harvesting effects on Paracentrotus 713 lividus population structure: a case study from northwestern Sardinia, Italy, before and after the fishing season. Journal of Coastal Research 28:570-575.

715

716

717

718

719

720

721

722

723

724

725

726

727

728

729

730

731

Paterno M, Schiavina M, Aglieri G, Ben Souissi J, Boscari E, Casagrandi R, Chassanite A, Chiantore M, Congiu L, Guarnieri G, Krsuchel C, Macic V, Marino I, Papetti C, Patarnello T, Zane L, Melià P. 2017. Population genomics meet Lagrangian simulations: Oceanographic patterns and long larval duration ensure connectivity among Paracentrotus lividus populations in the Adriatic and Ionian seas. Ecology and Evolution 7:2463-2479.

Pavesi F, Basoni A, Fugazza C, Menegon S, Oggioni A, Pepe M, Tagliolato P, Carrara P. 2016. EDI - A template-driven metadata editor for research data. Journal of Open Research Software. DOI: doi.org/10.5334/jors.106, 2016.

Pennington JT. 1985. The ecology of fertilization of echinoid eggs: the consequences of sperm dilution, adult aggregation, and synchronous spawning. the biological bulletin 169:417-430. DOI: https://doi.org/10.2307/1541492.

Perry RI, Zhang Z, Harbo R. 2002. Development of the green sea urchin fishery in BC - back from the brink using a precautionary framework. Fisheries Research 55:253-266.

Piazzi L, Ceccherelli G. 2019. Effect of sea urchin human harvest in promoting canopy forming algae restoration. Estuarine, Coastal and Shelf Science 219:273-277. DOI: 10.1016/j.ecss.2019.02.028. 
732

733

734

735

736

737

738

739

740

741

742

743

744

745

746

747

748

749

750

751

752

assess and address environmental non-compliance. Aquatic Conservation: Marine and Freshwater Ecosystems:n/a-n/a. DOI: 10.1002/aqc.2632.

Prado P, Farina S, Tomas F, Romero J, Alcoverro T. 2008. Marine protection and meadow size alter fish herbivory in seagrass ecosystems. Marine Ecology-Progress Series 371:11-21. DOI: $10.3354 /$ meps07662.

Prado P, Tomas F, Pinna S, Farina S, Roca G, Ceccherelli G, Romero J, Alcoverro T. 2012. Habitat and scale shape the demographic fate of the keystone sea urchin Paracentrotus lividus in mediterranean macrophyte communities. PLoS ONE 7:e35170. DOI: 10.1371/journal.pone.0035170.

R Core Team. 2014. R: A language and environment for statistical computing. R Foundation for Statistical Computing.

Ranney J, Bruner M, Levenson JB. 1981. Importance of edge in the structure and dynamics of forest islands. Ecological studies; analysis and synthesis.

Romagnoni G, Kvile KØ, Dagestad KF, Eikeset AM, Kristiansen T, Stenseth NC, Langangen Ø. 2020. Influence of larval transport and temperature on recruitment dynamics of North Sea cod (Gadus morhua) across spatial scales of observation. Fisheries Oceanography 29:324339. DOI: $10.1111 /$ fog. 12474 .

Sala E. 1997. Fish predators and scavengers of the sea urchin Paracentrotus lividus in protected areas of the north-west Mediterranean Sea. Marine Biology 129:531-539.

Sala E, Ballesteros E, Dendrinos P, Di Franco A, Ferretti F, Foley D, Fraschetti S, Friedlander A, Garrabou J, Güçlüsoy H, Guidetti P, Halpern BS, Hereu B, Karamanlidis AA, Kizilkaya Z, 
753

754

755

756

757

758

759

760

761

762

763

764

765

766

767

768

769

770

771

772

773

Macpherson E, Mangialajo L, Mariani S, Micheli F, Pais A, Riser K, Rosenberg AA, Sales M, Selkoe KA, Starr R, Tomas F, Zabala M. 2012. The Structure of Mediterranean Rocky Reef Ecosystems across Environmental and Human Gradients, and Conservation Implications. Plos One 7:e32742. DOI: 10.1371/journal.pone.0032742.

Sala E, Zabala M. 1996. Fish predation and the structure of the sea urchin Paracentrotus lividus populations in the NW Mediterranean. Marine Ecology Progress Series 140:71-81. DOI: $10.3354 /$ meps 140071.

Schmidt K, Kuijper D. 2015. A "death trap" in the landscape of fear. Mammal Research 60:275284. DOI: $10.1007 / \mathrm{s} 13364-015-0229-\mathrm{x}$.

Spedicato MT, Poulard J, Politou C, Radtke K, Lembo G, Petitgas P. 2010. Using the ALADYM simulation model for exploring the effects of management scenarios on fish population metrics. 165:153-165.

Steneck R, Graham M, Bourque B, Corbett D, Erlandson J, Estes J, Tegner M. 2002. Kelp forest ecosystems: biodiversity, stability, resilience and future. Environmental Conservation $29: 436-459$.

Tegner M, Dayton P. 1977. Sea urchin recruitment patterns and implications of commercial fishing. Science 196:324-326. DOI: 10.1126/science.847476.

Tegner M, Dayton P. 2000. Ecosystem effects of fishing in kelp forest communities. I. ICES Journal of Marine Science 57.

Tomas F, Romero J, Turon X. 2005. Experimental evidence that intra-specific competition in seagrass meadows reduces reproductive potential in the sea urchin Paracentrotus lividus

Peer) reviewing PDF | (2020:03:47281:2:0:NEW 3 Sep 2020) 
775 Tomas F, Turon X, Romero J. 2004. Settlement and recruitment of the sea urchin Paracentrotus 776 lividus in two contrasting habitats in the Mediterranean. Marine Ecology Progress Series 282:173-184. and duration of the pelagic larval stage determine seascape-wide connectivity of marine populations. Integrative and Comparative Biology 52:525-537. DOI: 10.1093/icb/ics101.

781

782

783

784

785

786

787

790

791

792

793

794

Umgiesser G, Canu DM, Cucco A, Solidoro C. 2004. A finite element model for the Venice Lagoon. Development, set up, calibration and validation. Journal of Marine Systems 51:123145. DOI: 10.1016/j.jmarsys.2004.05.009.

Wallner-Hahn S, de la Torre-Castro M, Eklöf JS, Gullström M, Muthiga N a., Uku J. 2015. Cascade effects and sea-urchin overgrazing: An analysis of drivers behind the exploitation of sea urchin predators for management improvement. Ocean \& Coastal Management 107:1627. DOI: 10.1016/j.ocecoaman.2015.01.010.

Whittingham MJ, Stephens PA, Richard B, Freckleton RP. 2006. Why do we still use stepwise modelling in ecology and behaviour? Journal of Animal Ecology 75:1182-1189. DOI: 10.1111/j.1365-2656.2006.01141.x.

Wing S. 2009. Decadal scale dynamics of sea urchin population networks in Fiordland, New Zealand are driven by juxtaposition of larval transport against benthic productivity gradients. Marine Ecology Progress Series 378:25-134. DOI: https://doi.org/10.3354/meps07878.

Zecchetto S, della Valle A, De Biasio F, Quattrocchi G, Satta A, Antognarelli F, Cadau E, Cucco 
795

796

797

798

799

800

801

802

803
A. 2016. The wind-measuring system in the Gulf of Oristano: a support for coastal-scale oceanographic applications. Journal of Operational Oceanography 9:144-154. DOI: $\square$ http://dx.doi.org/10.1080/1755876X.2015.1118806.

Zuur AF, Ieno EN, Walker NJ, Saveliev AA, Smith GH. 2009. Mixed effects models and extensions in ecology with R. New York: Springer. 
Figure 1

Diagram describing sea urchin population dynamics.

Letters represent different life stages of populations: a) commercial stock and main reproducers of sea urchin populations, b) larval supply for populations, c) settlement in suitable habitats, d) interactions with habitat structure for food and shelter, e) predator-prey interactions with local predator community, f) fishing pressure both on fish and sea urchins.

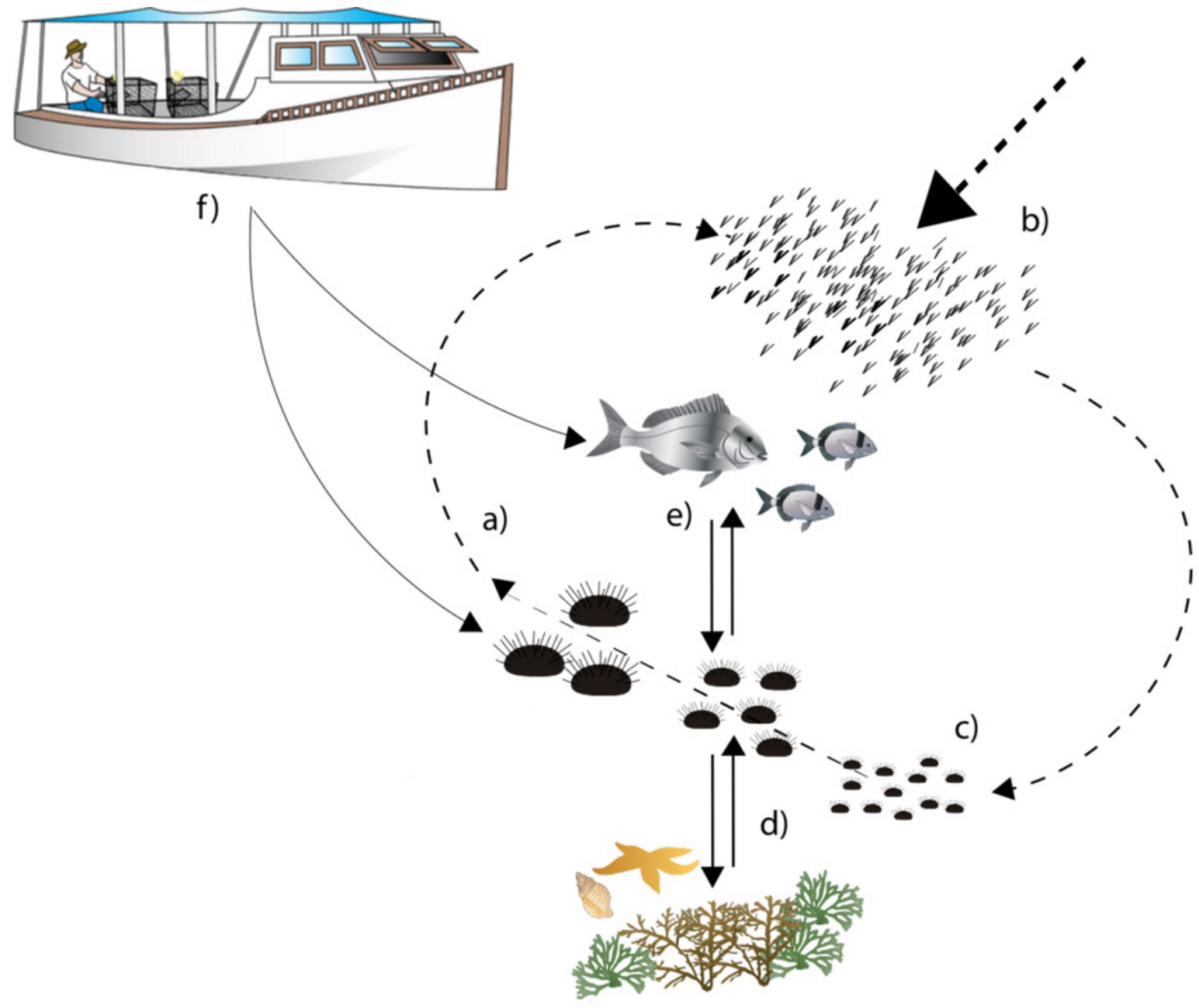


Figure 2

Detailed digital mapping of geomorphology in the study area

Colours indicatedifferent sectors and types of habitats: Calcareous rock (CR in grey), Granite (GR in light blue), Basalt (BA in red), Posidonia oceanica patchy meadow (PM in dark green), Posidonia oceanica continuous meadow (CM in light green) and sandy bottom (in yellow). 


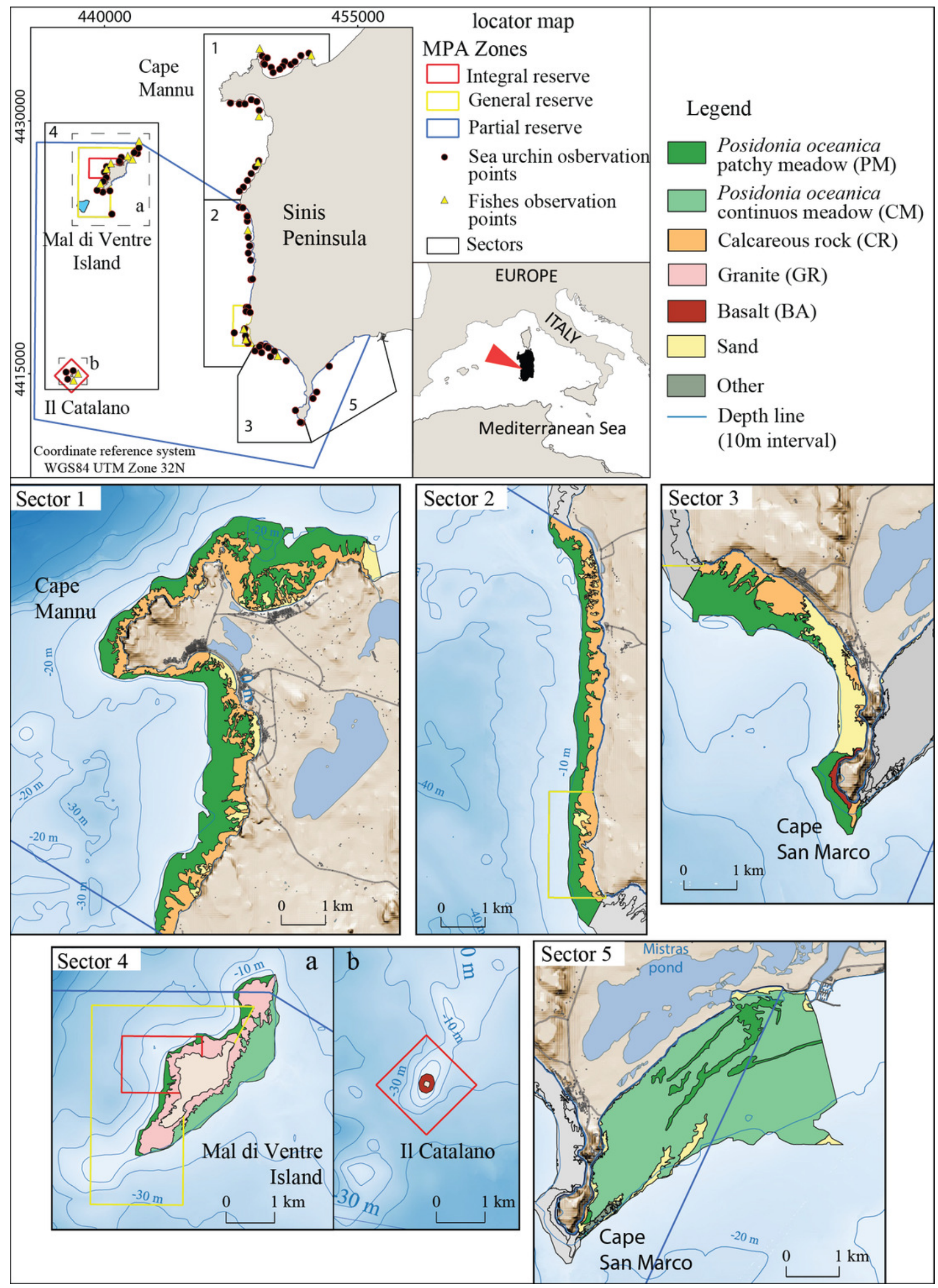


Figure 3

Detailed digital mapping of hydrodynamism in the study area.

Map representing average bottom current speed obtained by the oceanographic model in the area of interest during six months from spawning time to the period of settlement (JanuaryJune). 


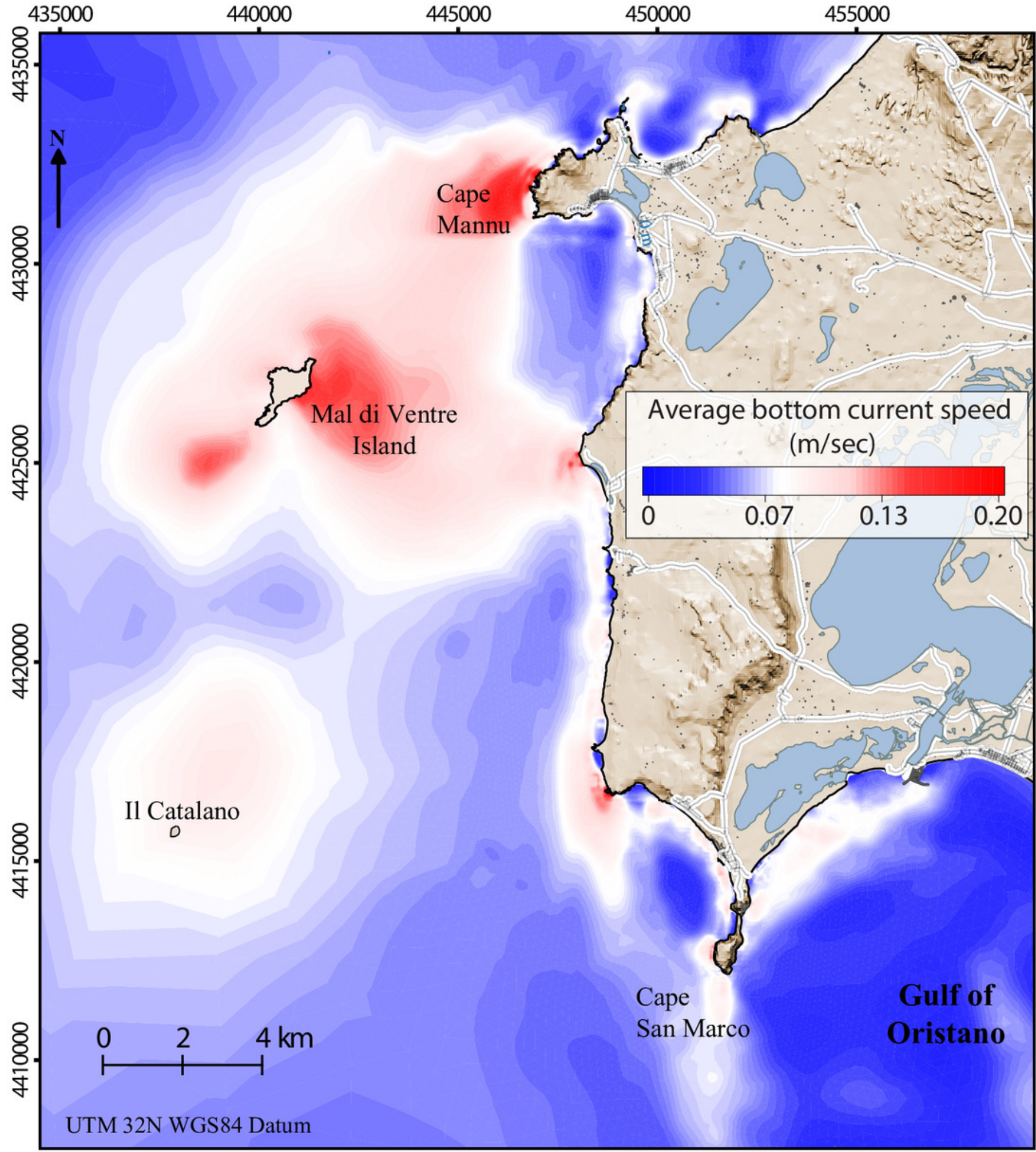


Figure 4

Graphs representing different population structures.

Populations of each type of habitat in each sector: calcareous rock of sector 1(CR-1), patchy meadow of sector 1 (PM-1), calcareous rock of sector 2 (CR-2), patchy meadow of sector 2 (PM-2), calcareous rock of sector 3 (CR-3), patchy meadow of sector 3 (PM-3), basalt of sector 3 (BA-3), granite of sector 4 (GR-4), basalt of sector 4 and continuous meadow of sector 5 (CM-5). 


\section{Population structures}
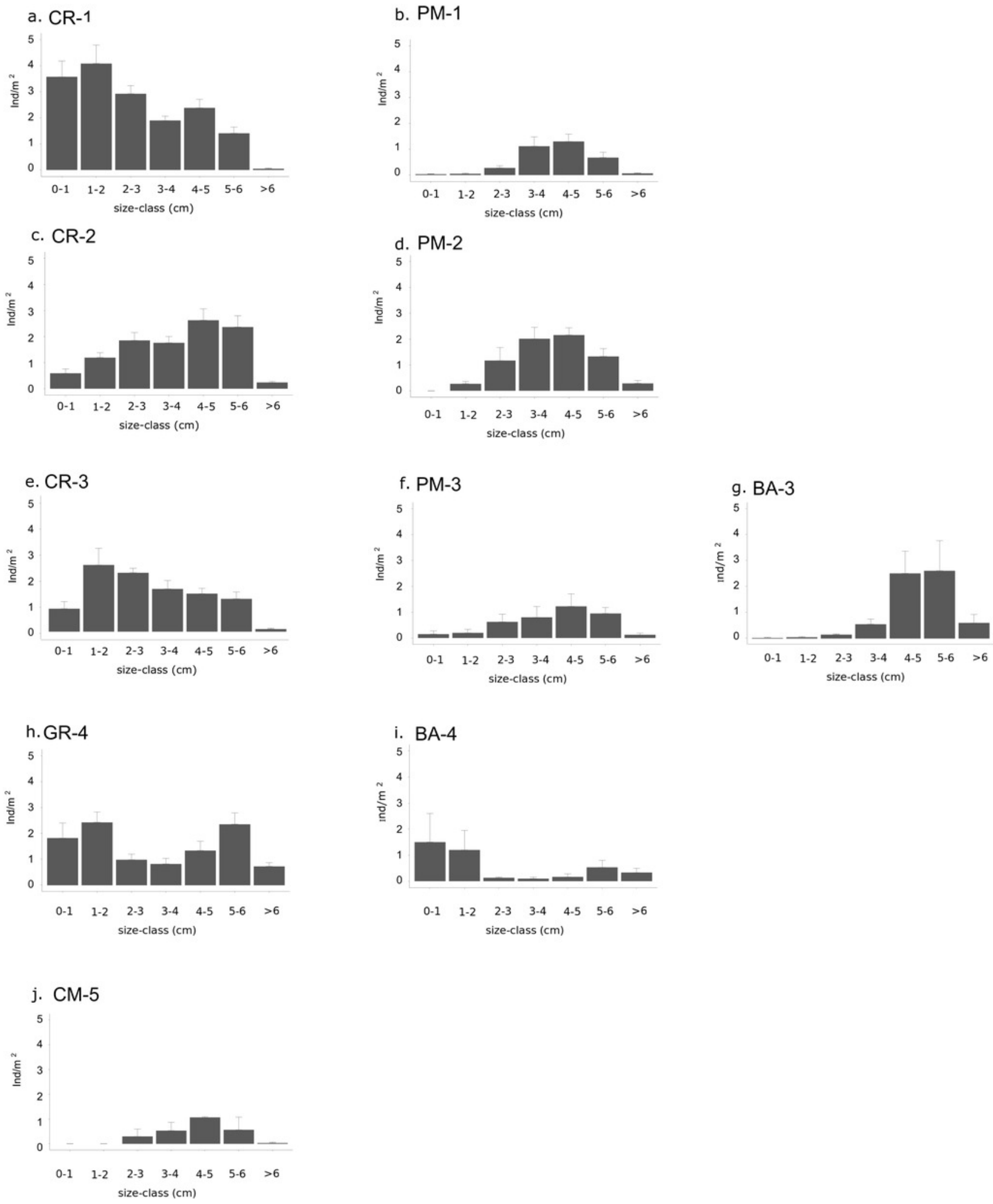


\section{Figure 5}

Graphs representing relationships between sea urchin densities and environmental constraints.

In rocky habitats a) density of recruits is correlated with the average bottom current speed (Spearman's rank correlation) and b) density of middle-sized sea urchins with predatory fish density (Pearson's correlation) Number of points used in the graph a corresponds to the sea urchin sampling stations while in the graph $b$ to the stations of fish visual census.
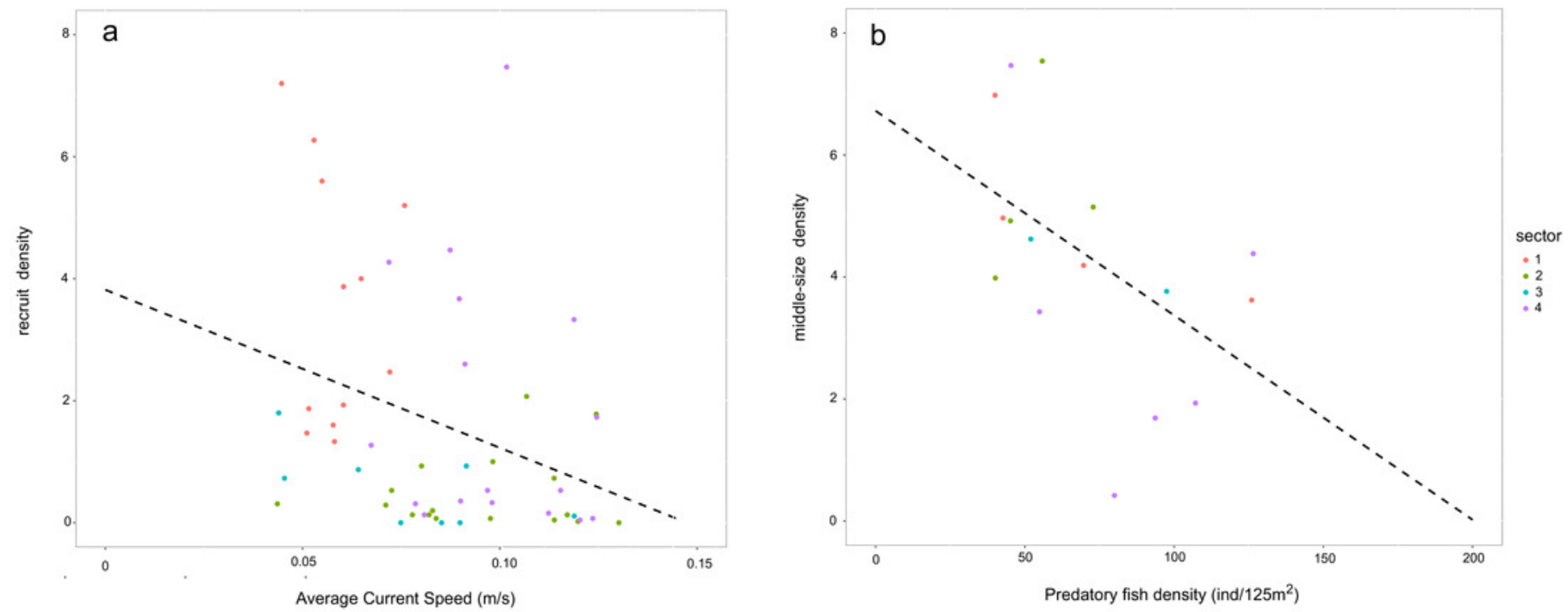


\section{Table $\mathbf{1}$ (on next page)}

Table showing differences in average bottom current speed and predatory fish density between sectors (in sector 5 only one observation was carried out). 


\begin{tabular}{|c|c|c|c|c|c|}
\hline Sector & $\begin{array}{l}\text { Total } \\
\text { area } \\
\left(\mathrm{Km}^{2}\right) \\
\end{array}$ & $\begin{array}{l}\text { Average Current } \\
\text { Speed } \\
(\mathrm{m} / \mathrm{s}) \\
\end{array}$ & $\begin{array}{l}\text { Average } \\
\text { predatory fish } \\
\left(\text { ind } / 125 \mathrm{~m}^{2}\right) \\
\end{array}$ & $\begin{array}{l}\text { Total sea } \\
\text { urchin density }\end{array}$ & $\begin{array}{l}\text { Stock } \\
\text { proportion (\%) }\end{array}$ \\
\hline 1 & 12.7 & $0.05 \pm 0.003$ & $69.6 \pm 20$ & $9.9 \pm 1.1$ & $15.1 \pm 2.3$ \\
\hline 2 & 5.1 & $0.09 \pm 0.004$ & $53.5 \pm 7.2$ & $8.9 \pm 1.3$ & $23.3 \pm 2.2$ \\
\hline 3 & 4.3 & $0.07 \pm 0.007$ & $74.8 \pm 22.8$ & $6.9 \pm 1.5$ & $28.7 \pm 4.7$ \\
\hline 4 & 3.8 & $0.10 \pm 0.004$ & $84.6 \pm 12.6$ & $7.5 \pm 1.7$ & $27.8 \pm 3.6$ \\
\hline 5 & 11.9 & $0.07 \pm 0.003$ & - & $2.5 \pm 0.2$ & $20.0 \pm 1.8$ \\
\hline
\end{tabular}

1 
Table 2 (on next page)

Spatial configuration of sampled habitats for each study sector.

Dash means no samplings were carried out. 


\begin{tabular}{|c|c|c|c|c|c|c|c|c|c|}
\hline Sector & Habitat & code & $\begin{array}{c}\mathrm{N}^{0} \text { of } \\
\text { samplings }\end{array}$ & $\begin{array}{l}\text { Area } \\
\left(\mathrm{Km}^{2}\right)\end{array}$ & $\begin{array}{l}\text { PD } \\
\left(\mathrm{n} / \mathrm{Km}^{2}\right)\end{array}$ & $\begin{array}{c}\text { P/A ratio } \\
(1 / \mathrm{m})\end{array}$ & $\begin{array}{l}\text { MPS } \\
\left(\mathrm{Km}^{2}\right)\end{array}$ & $\begin{array}{l}\text { LPI } \\
(\%)\end{array}$ & $\begin{array}{l}\text { IJI } \\
(\%)\end{array}$ \\
\hline \multirow{3}{*}{1} & Calcareous Rock & CR-1 & 12 & 4.5 & 1.01 & 21.1 & 0.10 & 3 & 68.6 \\
\hline & Patchy Meadow & PM-1 & 12 & 7.2 & 0.16 & 11.0 & 0.72 & 5.3 & 55.3 \\
\hline & Sand & & - & 1.0 & - & - & - & - & - \\
\hline \multirow[t]{3}{*}{2} & Calcareous Rock & CR-2 & 15 & 2.5 & 0.62 & 15.2 & 0.31 & 17 & 98.9 \\
\hline & Patchy Meadow & PM-2 & 7 & 2.3 & 0.08 & 13.2 & 2.28 & 17.8 & 46.3 \\
\hline & Sand & & - & 0.3 & - & - & - & - & - \\
\hline \multirow{4}{*}{3} & Calcareous Rock & CR-3 & 5 & 1.0 & 0.32 & 16.2 & 0.17 & 4.5 & 44.6 \\
\hline & Patchy Meadow & PM-3 & 4 & 2.0 & 0.32 & 10.4 & 0.33 & 8.2 & 61.7 \\
\hline & Basalt & BA-3 & 4 & 0.1 & 0.05 & 0.3 & 0.18 & 0.6 & 33.9 \\
\hline & Sand & & - & 1.2 & - & - & - & - & - \\
\hline \multirow{4}{*}{4} & Granite & GR-4 & 14 & 1.8 & 0.02 & 16.4 & 1.85 & 2.9 & 62.7 \\
\hline & Basalt & BA-4 & 3 & 0.1 & 0.02 & 21.4 & 0.08 & 0.1 & 0 \\
\hline & Patchy Meadow & & - & 0.5 & - & - & - & - & - \\
\hline & Cont. Meadow & & - & 1.4 & - & - & - & - & - \\
\hline \multirow{3}{*}{5} & Cont. Meadow & CM-5 & 3 & 11.1 & 2.6 & 2.1 & 3.7 & 42.6 & 5.5 \\
\hline & Other & & - & 0.1 & - & - & - & - & - \\
\hline & Sand & & - & 0.7 & - & - & - & - & - \\
\hline
\end{tabular}




\section{Table 3 (on next page)}

Densities of sea urchin size-classes representing population structures.

Mean sea urchins densities of the size-class range representing population structure in the different types of habitat. Size-class ranges $0-1 \mathrm{~cm}$ and $2-5 \mathrm{~cm}$ diameter represent recruits and middle-sized sea urchins respectively, whereas commercial stock size densities are represented beyond the dotted line and are not included in the analysis. 


\begin{tabular}{|c|c|c|c|c|c|c|c|c|}
\hline Sector & Habitat & $0-1 \mathrm{~cm}$ & $1-2 \mathrm{~cm}$ & $2-3 \mathrm{~cm}$ & $3-4 \mathrm{~cm}$ & $4-5 \mathrm{~cm}$ & $\begin{array}{l}\text { stock } \\
5-6 \mathrm{~cm}\end{array}$ & $>6 \mathrm{~cm}$ \\
\hline 1 & Calcareous Rock & $3.6 \pm 0.6$ & $4.1 \pm 0.7$ & $2.9 \pm 0.3$ & $1.9 \pm 0.2$ & $2.4 \pm 0.3$ & $1.4 \pm 0.2$ & 0 \\
\hline 1 & Patchy Meadow & 0 & 0 & $0.3 \pm 0.1$ & $1.1 \pm 0.4$ & $1.3 \pm 0.3$ & $0.7 \pm 0.2$ & $0.1 \pm 0$ \\
\hline 2 & Calcareous Rock & $0.6 \pm 0.2$ & $1.2 \pm 0.2$ & $1.9 \pm 0.3$ & $1.8 \pm 0.2$ & $2.6 \pm 0.4$ & $2.4 \pm 0.4$ & $0.2 \pm 0.1$ \\
\hline 2 & Patchy Meadow & 0 & $0.3 \pm 0.1$ & $1.2 \pm 0.5$ & $2 \pm 0.4$ & $2.1 \pm 0.3$ & $1.3 \pm 0.3$ & $0.3 \pm 0.1$ \\
\hline 3 & Calcareous Rock & $0.9 \pm 0.3$ & $2.5 \pm 0.6$ & $2.3 \pm 0.2$ & $1.6 \pm 0.3$ & $1.5 \pm 0.2$ & $1.2 \pm 0.3$ & $0.1 \pm 0$ \\
\hline 3 & Patchy Meadow & $0.1 \pm 0.1$ & $0.2 \pm 0.1$ & $0.6 \pm 0.3$ & $0.8 \pm 0.4$ & $1.2 \pm 0.5$ & $1 \pm 0.2$ & $0.1 \pm 0.1$ \\
\hline 3 & Basalt & 0 & $0.1 \pm 0$ & $0.1 \pm 0$ & $0.5 \pm 0.2$ & $2.5 \pm 0.9$ & $2.6 \pm 1.1$ & $0.6 \pm 0.3$ \\
\hline 4 & Granite & $1.9 \pm 0.6$ & $2.6 \pm 0.4$ & $1 \pm 0.2$ & $0.9 \pm 0.2$ & $1.4 \pm 0.4$ & $2.5 \pm 0.5$ & $0.8 \pm 0.1$ \\
\hline 4 & Basalt & $1.5 \pm 1.1$ & $1.2 \pm 0.7$ & $0.2 \pm 0$ & $0.1 \pm 0.1$ & $0.2 \pm 0.1$ & $0.5 \pm 0.3$ & $0.3 \pm 0.2$ \\
\hline 5 & Continuous Meadow & 0 & 0 & $0.3 \pm 0.3$ & $0.5 \pm 0.3$ & $1.1 \pm 0$ & $0.6 \pm 0.5$ & 0 \\
\hline
\end{tabular}




\section{Table 4 (on next page)}

Analysis of deviance table GLM model

a) density of under-commercial-size, b) density of recruit and c) density of middle-size sea urchins in function of Sector and Habitat as fixed factors. DF: degrees of freedom, DR: deviance residual, F: F statistics, P: probability of Type I error. 
1

\begin{tabular}{|l|l|l|l|l|l|}
\hline a. Response variable & Factor & DF & DR & F-value & p-value \\
\hline \multirow{2}{*}{ Density of under-commercial size } & Sector & 4 & 193.29 & 3.2592 & $\mathbf{0 . 0 1 6 3 8}$ \\
\cline { 2 - 6 } & Habitat & 3 & 801.33 & 18.0157 & $\mathbf{8 . 5 3 4 e - 0 9}$ \\
\cline { 2 - 6 } & Residual & 79 & & & \\
\hline b. Response variable & Factor & DF & MS & F-value & p-value \\
\hline Density of recruit & Sector & 3 & 44.68 & 6.038 & $\mathbf{0 . 0 0 1 0 3}$ \\
\cline { 2 - 6 } & Habitat & 3 & 101.21 & 13.677 & $\mathbf{4 . 2 6 e - 0 7}$ \\
\cline { 2 - 6 } & Residual & 69 & 7.40 & & \\
\hline c. Response variable & Factor & DF & DR & F-value & p-value \\
\hline Density of middle-size & Sector & 4 & 125.61 & 5.1458 & $\mathbf{0 . 0 0 1 0 6 7 6}$ \\
\cline { 2 - 6 } & Habitat & 3 & 130.73 & 7.1410 & $\mathbf{0 . 0 0 0 2 9 3 5}$ \\
\cline { 2 - 6 } & Residual & 78 & & & \\
\hline
\end{tabular}

2 


\section{Table 5 (on next page)}

Generalized Linear Model (GLM) showing the effects of the assessed explanatory variables on the density of commercial under-sized classes (TD $<5 \mathrm{~cm})$.

The Minimal Adequate Model $(\mathrm{AIC}=290.8$; $\mathrm{R}$-square $=0.468$ ) was obtained starting from Full Model ( $\mathrm{AIC}=295.5$; R-square=0.476) through the stepwise forward regression technique (Anova p-value $=0.55)$. Coefficient estimates (Estimate), standard errors $(S E), z$-values, and significance levels ( $p$-value) for variables are provided for fixed effects. Significant effects are given in bold. 
1

2

\begin{tabular}{|c|c|c|c|c|c|}
\hline \multicolumn{6}{|c|}{ Full Model } \\
\hline \multirow[t]{6}{*}{ Response variable } & Effect & Estimate & $\mathbf{S E}$ & z-value & p-value \\
\hline & MPS & 0.310135 & 0.120982 & 2.563 & 0.0104 \\
\hline & PD & 1.073995 & 0.201901 & 5.319 & $1.04 e-07$ \\
\hline & IJI & 0.001116 & 0.004847 & 0.230 & 0.8179 \\
\hline & LPI & -0.011801 & 0.019027 & -0.620 & 0.5351 \\
\hline & $\mathrm{P} / \mathrm{A}$ ratio & 0.007291 & 0.015867 & 0.460 & 0.6459 \\
\hline \multicolumn{6}{|c|}{ Minimal Adequate Model } \\
\hline Response variable & Effect & Estimate & $\overline{\text { SE }}$ & z-value & p-value \\
\hline \multirow[t]{2}{*}{ Sea urchin density } & MPS & 0.3758 & 0.0861 & 4.365 & $1.27 \mathrm{e}-05$ \\
\hline & PD & 1.1459 & 0.1381 & 8.300 & $2 e-16$ \\
\hline
\end{tabular}

3

4

5

6 